\title{
RESPONSIVITAS PELAYANAN PUBLIK DALAM PENGURUSAN SURAT IZIN \\ USAHA PERDAGANGAN DI DINAS PENANAMAN MODAL DAN PELAYANAN TERPADU SATU PINTU (DPMPTSP) KABUPATEN SINJAI
}

\section{RESPONSIVITY OF PUBLIC SERVICES IN ARRANGEMENT OF TRADE BUSINESS LICENSE LETTERS IN THE CAPITAL INVESTMENT AND INTEGRATED SERVICE SERVICE (DPMPTSP) SINJAI DISTRICT}

\author{
Novayanti Sopia Rukmana \\ Universitas Negeri Makassar \\ J1. A. P. Pettarani, Tidung, Kota Makassar \\ E-mail : novayanti@unm.ac.id \\ Ismaniar Ismail \\ STISIP Muhammadiyah Sinjai \\ Jl. Teuku Umar No.8 B, Biringere, Sinjai Utara, Kabupaten Sinjai \\ E-mail : ismaniar34@gmail.com
}

Naskah diterima tanggal 29 Oktober 2019. Naskah direvisi tanggal 20 November 2019. Naskah disetujui tanggal 15 Desember 2019

\begin{abstract}
Abstrak
Lahirnya pola pelayanan terpadu satu pintu merupakan salah satu upaya pemerintah untuk memberikan pelayanan yang prima (service excellent) terkait pembuatan SIUP. Penelitian ini bertujuan untuk mengetahui responsivitas pelayanan publik dalam pengurusan Surat Izin Usaha Perdagangan (SIUP) di Dinas Penanaman Modal dan Pelayanan Terpadu Satu Pintu (DPMPTSP) Kabupaten Sinjai. Jenis penelitian yang digunakan adalah kualitatif yang bersifat deskriptif, yaitu menjelaskan fenomena terkait responsivitas pengurusan SIUP. Pengumpulan data dilakukan dengan cara observasi dan wawancara mendalam dengan key informan. Pengolahan dan analisis data dilakukan melalui reduksi data, penyajian data, dan penarikan kesimpulan/verifikasi hasil penelitian. Berdasarkan penelitian, dapat disimpulkan bahwa responsivitas pelayanan publik dalam pengurusan SIUP di DPMPTSP Kabupaten Sinjai sudah berjalan dengan baik. Hal ini dapat tergambar dengan jelas dari hasil observasi terhadap 6 indikator responsivitas, yakni kemampuan merespon masyarakat, kecepatan melayani, ketepatan melayani, kecermatan, ketepatan waktu, dan kemampuan menanggapi keluhan/aduan dari masyarakat. Namun, tak dapat dipungkiri, ada faktor penghambat yang menjadi kendala dalam proses penerbitans surat izin usaha perdagangan, yakni komunikasi antara aparatur dengan pemohon izin usaha serta lokasi usaha pemohon yang cenderung jauh untuk dijangkau.
\end{abstract}

Kata Kunci : Pelayanan Publik, Responsivitas, Surat Izin Usaha Pedagangan (SIUP)

\begin{abstract}
The birth of the one-stop service pattern is one of the government's efforts to provide excellent service related to the making of SIUP. This study aims to determine the responsiveness of public services in managing the Surat Izin Usaha Perdagangan (SIUP) in Dinas Penanaman Modal dan Pelayan Terpadu Satu Pintu (DPMPTSP) Kabupaten Sinjai. The type of research used is descriptive qualitative, which explains the phenomena in depth related to responsiveness of SIUP. Data collection is done by observation and in-depth interview with key informants. Data processing and analysis is done through data reduction, data presentation, and research conclusions. Based on the research, it can be concluded that the responsiveness of public services in managing SIUP in DPMPTSP Kabupaten Sinjai has gone well. This can be clearly illustrated from the results of observations on 6 indicators of responsiveness, namely the ability to respond to the community, speed of service, accuracy of service, accuracy, timeliness, and the ability to
\end{abstract}


respond to complaints from the public. However, it cannot be denied, there are inhibiting factors that become obstacles in the process of issuing trade business licenses, namely the communication between the apparatus and the applicant's business license and the business location of applicants who tend to be far to reach.

Keywords: Public Service, Responsiveness, Surat Izin Usaha Perdagangan (SIUP)

\section{PENDAHULUAN}

\section{Latar Belakang}

Responsivitas sebagai salah satu elemen dari good governance berperan penting dalam upaya mengenali kebutuhan masyarakat, menyusun agenda dan prioritas pelayanan serta mengembangkan program-program pelayanan publik sesuai dengan kebutuhan dan aspirasi masyarakat. Sebab responsivitas ini mengukur daya tanggap birokrasi terhadap harapan, keinginan dan aspirasi serta tuntutan pengguna jasa. Organisasi yang memilki repsonsivitas rendah dengan sendirinya memilki kinerja pelayanan yang jelek juga (Dwiyanto : 2006). Salah satu bentuk pelayanan publik yang acapkali mendapat sorotan tajam dari masyarakat adalah pelayanan administratif dalam bidang pelayanan perizinan.

Fenomena yang kerap kali ditemukan dalam pelayanan perizinan, yaitu: Pertama, pelayanan yang tidak sesuai dengan standar pelayanan perizinan terpadu. Kedua, waktu pengurusan surat izin yang berlarut-larut. Ketiga, kuantitas dan kualitas sumber daya manusia yang tidak mendukung dalam pelayanan perizinan. Salah satu jenis pelayanan perizinan, yaitu pengurusan Surat Izin Usaha Perdagangan (SIUP).

Surat Izin Usaha Perdagangan merupakan legalitas usaha yang berfungsi sebagai alat untuk membina, mengarahkan, mengawasi dan menerbitkan kegiatan usaha dibidang perdagangan menuju pelaksanaan tertib usaha. Pemerintah sebagai penyedia layanan, tentu harus memberikan pelayanan yang prima (service excellent) terkait pembuatan SIUP.

Berdasarkan hasil penelitian yang dilakukan oleh Sukmawati (2016) terkait Akuntabilitas Proses Pelayanan Surat Izin
Usaha Perdagangan (SIUP) di Kota Makassar, menujukan bahwa pelayanan SIUP belum sepenuhnya akuntabel. Hal ini dilihat dari (a) aspek prosedur pelayanan belum terlaksana dengan baik yakni pada sistem pembayaran retribusi izin usaha, (b) besaran biaya yang dikenakan kepada masyarakat belum sesuai dengan standar biaya yang ditetapkan dan (c) jangka waktu pelayanan. Dimana penyelesaian izin usaha belum terlaksana dengan tepat waktu.

Namun, hasil penelitian berbeda ditujukan oleh Masnyur (2015) terkait Revitalisasi Birokrasi dalam Pelayanan Perizinan di Kabupaten Sinjai, dimana pelayanan perizinan di Kabupaten Sinjai dikategorikan berkualitas dilihat dari dimensi: assurance (jaminan kualitas pelayanan), empathy (empati aparatur), tangible (fasilitas fisik yang memadai), reliable (kehandalan), dan responsiveness (daya tanggap).

Dinas Penanaman Modal dan Pelayanan Terpadu Satu Pintu (DPMPTSP) Pemerintah Kabupaten Sinjai Provinsi Sulawesi Selatan terhitung sejak 1 April mengelola 37 jenis perizinan dan non perizinan. Hal ini didasarkan pada peraturan Bupati Sinjai No. 9 Tahun 2016 tentang Pelimpahan Kewenangan Pengelolaan dan Penandatanganan Perizinan dan Non perizinan pada Badan Penanaman Modal dan Pelayanan Perizinan Kabupaten Sinjai. Dengan adanya Pelayanan Terpadu Satu Pintu (PTSP), iklim investasi di Kabupaten Sinjai semakin bergairah (sinjai.info).

\section{Rumusan Masalah}

Berdasarkan latar belakang, maka rumusan masalah dalam penelitian ini yaitu : Bagaimana responsivitas pelayanan publik dalam pengurusan Surat Izin Usaha Perdagangan di Dinas Penanaman Modal 
dan Pelayanan Terpadu Satu Pintu (DPMPTSP) Kabupaten Sinjai ?

\section{Tujuan Penelitian}

Adapun tujuan dari penelitian ini, yaitu untuk mengetahui responsivitas pelayanan publik dalam pengurusan Surat Izin Usaha Perdagangan di Dinas Penanaman Modal dan Pelayanan Terpadu Satu Pintu (PTSP) Kabupaten Sinjai.

\section{Manfaat Penelitian} yaitu:

Adapun manfaat dari penelitian ini,

a. Manfaat Akademik

1. Dapat memberikan sumbangan pemikiran terkait responsivitas pelayanan publik dalam pengurusan Surat Izin Usaha Perdagangan di Dinas Penanaman Modal dan Pelayanan Terpadu Satu Pintu (PTSP) Kabupaten Sinjai

2. Dapat memberikan kontribusi pemikiran bagi disiplin ilmu Administrasi Negara, khusunya tentang pelayanan publik.

b. Manfaat Praktis

1. Dapat dijadikan sebagai sumber referensi bagi peneliti/penulis lain yang hendak meneliti tentang pelayanan perizinan di Kabupaten Sinjai

2. Dapat dijadikan sebagai pedoman bagi Pemerintah Kabupaten Sinjai dalam pengambilan keputusan berkenaan dengan peningkatan responsivitas pelayanan publik dalam pengurusan Surat Izin Usaha Perdagangan di Dinas Penanaman Modal dan Pelayanan Terpadu Satu Pintu (PTSP).

\section{TINJAUAN PUSTAKA}

\section{Responsivitas}

Menurut Dwiyanto (2006: 50), responsivitas adalah kemampuan organisasi untuk mengenali kebutuhan masyarakat, menyusun agenda dan prioritas pelayanan, dan mengembangkan program-program pelayanan publik sesuai dengan kebutuhan dan aspirasi masyarakat. Responsivitas merupakan konsep menyangkut kemampuan aparatur dalam menghadapi dan mengantisipasi aspirasi baru, perkembangan baru, tuntutan baru, dan pengetahuan baru. Birokrasi harus merespon secara cepat agar tidak tertinggal dalam menjalankan tugas dan fungsinya.

Zeithaml dkk (Hardiyansyah, 2011:46-47), menyatakan bahwa responsivitas adalah kerelaan untuk menolong customers dan menyelenggarakan pelayanan secara ikhlas, serta kemauan untuk membantu konsumen bertanggung jawab terhadap mutu layanan yang diberikan. Adapun indikator responsivitas menurut Zeithaml dkk, sebagai berikut:

a. Merespon setiap pelanggan/pemohon yang ingin mendapatkan pelayanan. Hal ini Sikap aparat dalam memberikan pelayanan dapat dilihat misalnya dari kesopanan dan keramahan pegawai dalam memberikan pelayanan kepada semua pengguna jasa

b. Petugas/aparatur melakukan pelayanan dengan cepat. Menurut Mawarni (2014:5), pelayanan cepat yang dilakukan meliputi kesigapan dan ketulusan petugas dalam menjawab pertanyaan atau permintaan pelanggan.

c. Petugas/aparatur melakukan pelayanan dengan tepat. Menurut Kasmir (dalam Mawarni, 2014:6) pelayanan dengan tepat artinya pelayanan yang diberikan sesuai dengan keinginan pelanggan.

d. Petugas/aparatur melakukan pelayanan dengan cermat. Menurut Sutrisno (dalam Mawarni, 2014:11), pelayanan dengan cermat ialah selalu fokus dan sungguh-sungguh dalam melakukan memberikan pelayanan.

e. Petugas/aparatur melakukan pelayanan dengan waktu yang tepat. Pelayanan dengan waktu yang tepat menurut Hardiyansyah (2011:49), mengandung arti pelaksanaan pelayanan masyarakat akan diselesaikan dalam kurun waktu yang telah ditentukan.

f. Semua keluhan pelanggan direspon oleh petugas 
Dalam memahami hakikat responsivitas dalam pelayanan publik, ada tiga prinsip yang harus diperhatikan, yaitu:

a. Access, artinya warga negara berhak mengetahui apa kriteria kriteria perwakilan politiknya yang harus di terapkan dan alasannya

b. Choice. Sistem quasi market yang diterapkan dalam pelayanan. Selain itu ada pula sistem tambahan, seperti sistem complain yang mudah, pengawasan independent pihak eksternal, publikasi indikator kinerja yang diketahui publik.

c. Indikator : pengguna pelayanan memerlukan informasi tentang :

1. Eksistensi pelayanan

2. Tujuan pelayanan

3. Standar atau kualitas pelayanan yang ditawarkan

4. Hak untuk memanfaatkan pelayanan dan complain

\section{Pelayanan Publik}

Pelayanan pada hakikatnya adalah serangkaian kegiatan, karena itu proses pelayanan berlangsung secara rutin dan berkesinambungan, meliputi seluruh kehidupan organisasi dalam masyarakat. Proses yang dimaksudkan dilakukan sehubungan dengan saling memenuhi kebutuhan antara penerima dan pemberi pelayanan. Sebagaimana A.S. Moenir A (Pasolong, 2007: 128) menyatakan bahwa pelayanan adalah proses pemenuhan kebutuhan melalui aktivitas orang lain yang langsung inilah yang dinamakan pelayanan.

Jadi, dapat disimpulkan bahwa pelayanan publik adalah segala bentuk jasa pelayanan baik dalam bentuk barang publik maupun jasa publik yang pada prinsipnya menjadi tanggung jawab dan dilaksanakan oleh instansi pemerintah di pusat, di daerah, dan di lingkungan Badan Usaha Milik Negara atau Badan Usaha Milik Daerah, dalam rangka pelaksanaan ketentuan peraturan perundang- undangan.

Dalam proses kegiatan pelayanan publik terdapat beberapa faktor atau unsur yang mendukung jalannya kegiatan (A.S. Moenir, 2002: 8), yaitu:

a. Sistem, prosedur dan metode, yaitu dalam pelayanan publik perlu adanya sistem informasi, prosedur dan metode yang mendukung kelancaran dalam memberikan pelayanan.

b. Personil, terutama ditekankan pada perilaku aparatur yang harus profesional, disiplin dan terbuka terhadap kritik dari pelanggan atau masyarakat.

c. Sarana dan prasarana pelayanan publik yang memadai.

Secara teoritis, tujuan pelayanan publik pada dasarnya adalah memuaskan masyarakat. Untuk mencapai kepuasan itu dituntut kualitas pelayanan publik yang profesional, kemudian Lijan Poltak Sinambela (2008:16) mengemukakan asasasas dalam pelayanan publik tercermin dari:

a. Transparansi. Hal ini artinya pelayanan itu bersifat terbuka, mudah dan dapat diakses oleh semua pihak yang membutuhkan dan disediakan secara memadai serta mudah dimengerti.

b. Akuntabilitas, artinya dapat dipertanggungjawabkan sesuai dengan ketentuan peraturan perundangundangan.

c. Kondisional, artinya sesuai dengan kondisi dan kemampuan pemberi dan penerima pelayanan dengan tetap berpegang pada prinsip efisiensi dan efektivitas.

d. Partisipatif bermakna mendorong peran serta masyarakat dalam penyelenggaraan pelayanan publik dengan memperhatikan aspirasi, kebutuhan dan harapan masyarakat.

e. Tidak diskriminatif dalam arti tidak membedakan suku, agama, ras, golongan, gender dan status ekonomi.

f. Keseimbangan hak dan kewajiban, artinya pemberi dan penerima pelayanan publik harus memenuhi hak dan kewajiban masing- masing pihak.

Penyelenggaraan pelayanan publik juga harus memiliki standar pelayanan dan dipublikasikan sebagai jaminan adanya kepastian bagi penerima pelayanan. "Standar pelayanan merupakan ukuran yang dibakukan dalam penyelenggaraan pelayanan publik yang wajib ditaati oleh 
pemberi dan atau penerima pelayanan". Kep. MENPAN No. 63 Tahun 2003: VB, meliputi:

a. Prosedur pelayanan. Prosedur pelayanan yang dibakukan bagi pemberi dan penerima pelayanan termasuk pengadaan.

b. Waktu penyelesaian. Waktu penyelesaian yang ditetapkan sejak saat pengajuan permohonan sampai dengan penyelesaian pelayanan termasuk pengaduan.

c. Biaya pelayanan. Biaya atau tarif pelayanan termasuk rinciannya yang dititipkan dalam proses pemberian pelayanan.

d. Produk Pelayanan. Hasil pelayanan yang akan diterima sesuai dengan ketentuan yang telah ditetapkan.

e. Sarana dan prasarana. Penyedia sarana dan prasarana pelayanan yang memadai oleh penyelenggara pelayanan publik.

f. Kompetensi petugas pemberi pelayanan. Kompetensi petugas pemberi pelayanan harus ditetapkan dengan tepat berdasarkan pengetahuan, keahlian, keterampilan, sikap dan perilaku yang dibutuhkan.

Asas dan standar pelayanan tersebut diatas merupakan pedoman dalam penyelenggaraan pelayanan publik oleh instansi pemerintah dan juga berfungsi sebagai indikator dalam penilaian serta evaluasi kinerja bagi penyelenggara pelayanan publik. Dengan adanya standar dalam kegiatan pelayanan publik ini diharapkan masyarakat bisa mendapatkan pelayanan yang sesuai dengan kebutuhan dan prosesnya memuaskan dan tidak menyulitkan masyarakat.

\section{Kerangka Pikir}

Berdasarkan konsep tersebut diatas, maka penulis menggambarkan state of the art penelitian ini sebagai berikut:

\section{METODE PENELITIAN}

\section{Lokasi dan Waktu Penelitian}

Penelitian ini berlokasi di Dinas Penanaman Modal dan Pelayanan Terpadu Satu Pintu (PTSP) Kabupaten Sinjai. Hal ini dikarenakan PTSP merupakan satu-

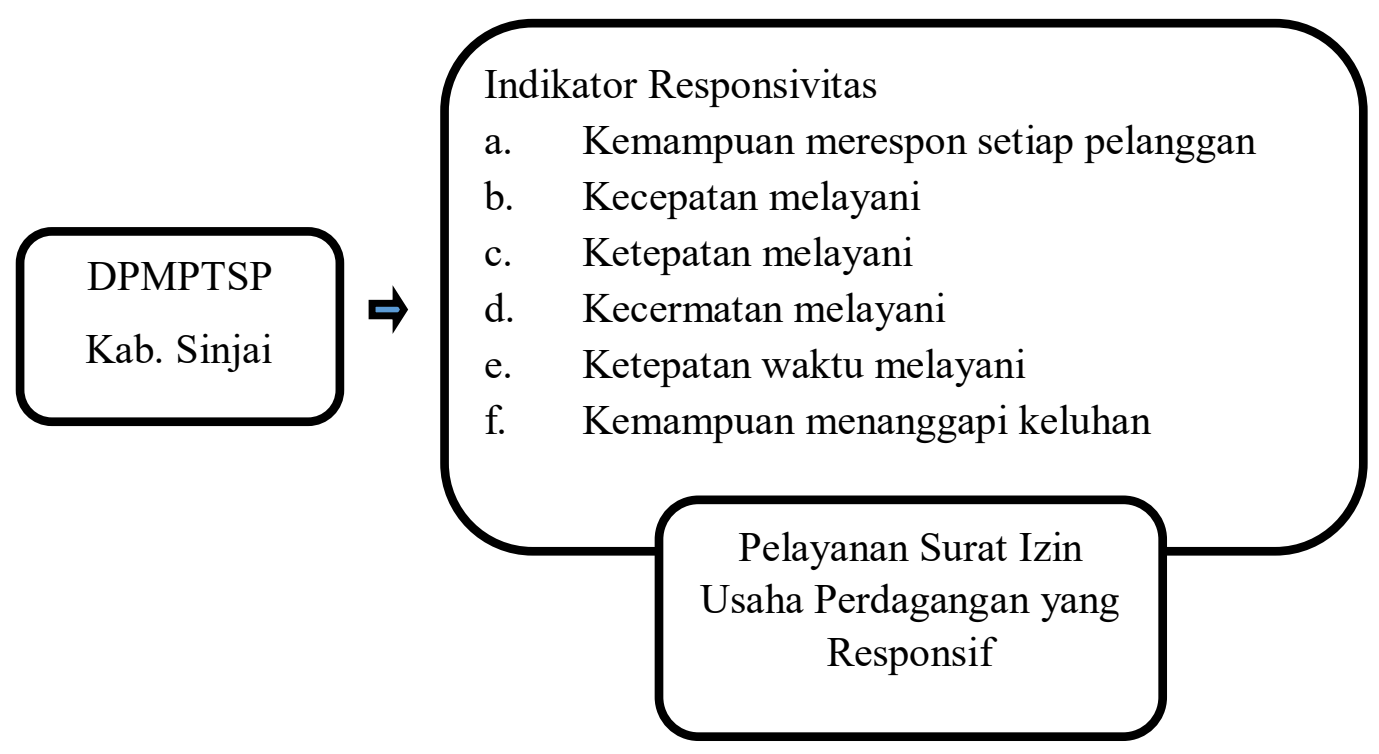

Gambar 1. State of the art 
satunya instansi publik yang memiliki wewenang untuk melayani masyarakat dalam pengurusan Surat Izin Usaha Perdagangan (SIUP) Kabupaten Sinjai. Penelitian ini dilakukan selama 3 bulan, yakni Oktober-Desember 2017.

\section{Jenis Penelitian}

Jenis penelitian yang digunakan adalah desain penelitian kualitatif. Penggunaan desain ini untuk melihat dan menjelaskan responsivitas pelayanan publik dalam pengurusan Surat Izin Usaha Perdagangan di Dinas Penanaman Modal dan Pelayanan Terpadu Satu Pintu Kabupaten Sinjai.

\section{Teknik Pengumpulan Data}

Teknik pengumpulan data yang dilakukan dalam penelitian ini adalah pertama, pengamatan (observasi) yang dilakukan berkaitan dengan pegawai dan masyarakat yang mengurus SIUP di Kabupaten Sinjai. Kedua, wawancara mendalam dilakukan kepada para informan yakni kepala dinas, kepala bidang perizinan, tim teknis dan pegawai DPMPTSP serta masyarakat yang mengurus SIUP

\section{Metode Analisis Data}

Teknik analisis data dalam penelitian ini mengacu pada beberapa tahapan sesuai dengan konsep Miles dan Huberman (Gita, 2016 : 13), yaitu dimulai dari reduksi data dan penyajian data Pada tahap akhir, peneliti melakukan penarikan kesimpulan atau verifikasi (conclusion drawing/ verification).

\section{HASIL DAN PEMBAHASAN}

Pelayanan pemenuhan kebutuhan publik merupakan tugas dari pemerintah. Pemerintah melaksanakan tugas tersebut berdasarkan pedoman yang memuat tentang kewajiban dan hak bagi masingmasing pihak penyelenggara pelayanan publik maupun penerima pelayanan publik. Kewajiban dan hak bagi setiap penyelenggara pelayanan publik maupun penerima pelayanan publik diwujudkan dan dipertegas melalui beberapa peraturan berupa undang-undang, dimana undang- undang tersebut dibuat sebagai salah satu bentuk tanggung jawab pemerintah dalam pelayanan publik sebagaimana yang termuat dalam Undang Undang Pelayanan Publik Nomor 25 Tahun 2009.

Melayani masyarakat dengan baik merupakan tanggung jawab bagi semua pegawai. Dengan demikian maka setiap pegawai harus melayani masyarakat dan mempelajari cara meningkatkan keterampilan untuk melayani. Di dalam keterampilan melayani, termasuk pula di dalamnya adalah penguasaan terhadap pengetahuan jasa layanan yang diberikan, karena hal ini akan menunjukan kepada masyarakat bahwa pegawai tersebut adalah seorang profesional di bidang Manajemen Pelayanan Publik. Seorang profesional dalam dunia pelayanan publik seharusnya menguasai kebutuhan masyarakat dan mengetahui cara memuaskan dan memenuhi kebutuhan masyarakat.

Kebutuhan dan aspirasi masyarakat merupakan faktor penting bagi pelayanan yang diberikan oleh pemerintah, karena dua hal tersebut dapat dijadikan sebagai tolak ukur bagi pelayanan publik. Oleh Karena itulah, birokrasi harus merespon secara cepat agar tidak tertinggal dalam menjalankan tugas dan fungsinya. (Tangkilisan, 2005:217).

Fandy Tjiptono (2005:14), responsivitas (daya tanggap) merupakan keinginan para staff untuk membantu para pelanggan dan memberikan pelayanan dengan tanggap. Dalam melakukan observasi dilapangan, peneliti membagi aspek responsivitas dalam 6 indikator, sebagaimana terinci dibawah ini:

1. Kemampuan merespon setiap kebutuhan masyarakat

Kemampuan merespon setiap masyarakat ini berkaitan dengan sikap aparat dalam memberikan pelayanan, seperti dari kesopanan dan keramahan pegawai serta kemampuan pegawai dalam menyesuaikan diri saat memberikan pelayanan kepada semua pengguna jasa (masyarakat). Sikap sopan dan ramah oleh petugas tentu yang menilai adalah masyarakat itu sendiri, Hal ini dikarenakan masyarakat sebagai pihak yang menerima dan merasakan pelayanan petugas. 
Berdasarkan observasi lapangan, sikap pegawai pada Dinas Penanaman Modal Terpadu Satu pintu (DPMPTSP) Kabupaten Sinjai dalam merespon masyarakat sudah memenuhi kriteria pelayanan publik yang baik. Menurut Dwiyanto (2008:63), keberadaan pegawai yang sopan dan ramah dalam merespon masyarakat yang ingin mengurus surat izin membuat masyarakat merasa diterima dan dihargai. Dalam hal ini kesopanan dan keramahan pegawai penyelenggara pelayanan publik merupakan hal yang sangat penting dan diperlukan di intansi manapun yang menyelenggarakan pelayanan publik.

Sikap baik pegawai DPMPTSP juga ditunjukkan melalui perlakuan sama. Perlakuan yang sama yang dimaksud adalah pegawai dalam memberikan pelayanan dan merespon keluhan masyarakat yang ingin mengurus surat izin usaha tidak memilih milih atau mendahulukan keluhan mana yang akan ditangani terlebih dahulu karena semua masyarakat memiliki hak yang sama yaitu mendapatkan pelayanan yang berkualitas dari penyelenggara pelayanan publik.

Indikator pelayanan publik dalam hal merespon setiap masyarakat dan pemohon dalam mengurus surat izin usaha pada DPMPTSP di Kabupaten sinjai dapat dikatakan memenuhi indikator pelayanan publik yang responsif sesuai dengan teori dalam penelitian ini yaitu Zeithaml dkk.

2. Kecepatan melayani

Pelayanan publik adalah segala kegiatan pelayanan yang dilaksanakan oleh penyelenggara pelayanan publik sebagi upaya pemenuhan kebutuhan penerima pelayanan maupun pelaksanaan ketentuan peraturan perundang-undangan [Keputusan Menteri Pendayagunaan Aparatur Negara (Menpan) Nomor 63/KEP/ M.PAN/7/2003]. Setiap penerima pelayanan publik tentu menginginkan untuk dilayani oleh penyelenggara pelayanan publik dengan cepat.

Konsep pelayanan yang cepat juga di artikan bahwa kesigapan dan ketulusan petugas/pegawai penyelenggara pelayanan publik dalam memberikan pelayanan serta menjawab petanyaan atau permintaan kepada masyarakat. Dalam hal ini pelayanan yang cepat artinya pegawai pada Dinas Penanaman Modal dan Pelayanan Terpadu Satu Pintu Kabupaten Sinjai pelayanan yang diberikan dalam mengurus surat izin usaha tidak lebih dari lima hari sesuai dengan aturan yang tertuang dalam Standar Operational Prosedur yang ada sehingga dapat memenuhi kriteria daalam pelayanan publik yang berkualitas.

Namun demikian, banyak masyarakat Kabupataen Sinjai yang tidak mengetahui lamanya waktu penerbitan SIUP. Bahkan ada yang menunggu hingga berbulan-bulan. Tentu hal ini merupakan suatu kendala dalam pelayanan publik. Menurut salah satu Tim Teknis DPMPTSP, yang menjadi kendala dalam melakukan survey sehingga seringkali menyebabkan surat izin terbit tidak sesuai dengan SOP, yaitu: masalah komunikasi. Dimana, saat ingin menijau lokasi, masyarakat yang mengajukan SIUP tidak berada dilokasi survey.

Padahal bilama menelisik lebih jauh, penyelenggaraan pelayanan publik yang memiliki standar pelayanan memuat beberapa komponen yang berguna sebagai jaminan yang menandakan kepastian bagi penerima layanan. Standar pelayanan yang dibuat perlu dipahami agar baik pemberi maupun penerima pelayanan mengetahui hak dan kewajiban masing-masing. Standar pelayanan publik digunakan sebagai pedoman penyelenggaraan pelayanan publik dan dapat dijadikan sebagai tolak ukur dalam menilai seberapa besar tingkat kepuasan penerima pelayanan publik, terutama bagi penerima pelayanan publik di intansi instansi pemerintahan.

Berdasarkan tabel berikut, diketahui bahwa ada peningkatan pengurusan surat izin usaha baik usaha yang skopnya kecil, Menengah dan Besar mulai dari tahun 2014- Oktober 2017.

3. Ketetapan melayani

Pelayanan yang diberikan oleh penyelenggara pelayanan publik kepada penerima pelayanan publik bukan hanya sekedar pelayanan cepat, melainkan juga pelayanan secara tepat. Pelayanan tepat 
Tabel 1. Jumlah Izin SIUP yang diterbitkan DPMPTSP

\begin{tabular}{|l|l|l|l|l|l|}
\hline \multirow{2}{*}{ No } & \multirow{2}{*}{ Tahun } & \multicolumn{2}{|c|}{ Jumlah Izin Yang diterbitkan } & \multirow{2}{*}{ Total } \\
\cline { 3 - 5 } & & Besar & Menengah & Kecil & \\
\hline 1 & 2014 & 4 & 30 & 319 & 353 \\
\hline 2 & 2015 & 3 & 18 & 584 & 605 \\
\hline 3 & 2016 & 2 & 29 & 886 & 917 \\
\hline 4 & $\begin{array}{l}\text { s/d Oktober } \\
2017\end{array}$ & 1 & 14 & 311 & 326 \\
\hline
\end{tabular}

Sumber: Bagian Data dan Informasi Kab. Sinjai

menurut Kasmir (dalam Mawarni, 2014:6), adalah jangan sampai terjadi kesalahan baik dalam hal pekerjaan maupun pembicaraan, dalam arti pelayanan yang diberikan sesuai dengan keinginan masyarakat.

Berkaitan dengan pelayanan dengan tepat yakni menyangkut cara penyampaian petugas terhadap masyarakat dalam proses pemberian layanan berjalan sesuai dengan yang semestinya. Dinas Penanaman Modal dan Pelayanan Terpadu Satu Pintu Kabupaten Sinjai sebagai instansi yang menerbitkan surat izin usaha melakukuan koordinasi dengan dinas-dinas lain yang terkait. Selain itu, koordinasi yang dilakukan antara pegawai dalam pengurusan dan penertiban surat izin usaha juga terjalin dengan baik. Adanya pembentukan Tim Teknis yang turun kelapangan sebagai bentuk koordinasi yang baik dimana Tim Teknis di bentuk berdasarkan jenis usaha yang akan diterbitkan.

Pada dasarnya agar dalam pelayanan publik tidak terjadi kesalahan kesalahan dalam pengurusaan izin usaha, sudah terbuat dalam Standar Operational Prosedur. Maksud dibuatnya SOP pelayanan pada DPMPTSP ini agar dapat digunakan sebagai pedoman bagi petugas untuk melaksanakan pelayanan publik secara profesional serta dapat meningkatkan citra dan kepercayaan masyarakat terhadap pelayanan perizinan. Selain itu, dibuatnya SOP ini agar adanya pemahaman, persamaan persepsi petugas pelaksanaan pelayanan publik akan tugas pokoknya, prosedurnya, aturan yang harus dilaksanakan.

Berdasarkan data yang diperoleh di lapangan, ketepatan melayani di Dinas penanaman Modal dan Pelayanan Terpadu Satu Pintu Kabupaten Sinjai menunjukkan bahwa pelayanan yang dilakukan oleh penyelenggara pelayanan publik kepada penerima layanan sudah memenuhi standar dalam ketepatan melayani. Hal ini ditujukan dengan masyarakat yang tidak perlu mundar-mandir ke dinas-dinas lain dalam mengurus SIUP karena sejak dini, pegawai DPMPTSP telah memberikan arahan dan informasi terkait hal-hal yang perlu dilengkapi masyarakat yang hendak mendapatkan SIUP.

Pelayanan kepada masyarakat pada dasarnya memberi gambaran tentang pendekatan dari seorang pegawai pada instansi pemerintah. Pada hakikatnya inti dari pelayanan kepada masyarakat adalah sikap menolong, bersahabat, dan profesional dalam memberikan pelayanan jasa atau produk dari suatu instansi yang memuaskan masyarakat dan menyebabkan masyarakat datang kembali untuk mohon pelayanan instansi tersebut. Pelayanan masyarakat menuntut setiap unsur di dalam lembaga tersebut untuk berempati kepada masyarakat. Memberikan pelayanan yang tepat kepada masyarakat mengandung pengertian sebagai kesanggupan dari birokrat pemerintah untuk menempatkan dirinya dari pihak masyarakat dan melihat hal-hal atau 
masalah-masalah dari sudut pandangan masyarakat.

4. Kecermatan melayani

Menurut Dwiyanto (2012: 69) untuk melihat responsivitas organisasi publik, dapat dilihat dari aspek keterbukaan informasi terhadap pengguna jasa. Kurangnya keterbukaan dan transparansi dalam penyampaian informasi dari birokrasi terkait pelayanan publik dapat membuat masyarakat menjadi frustasi dalam berurusan dengan pemerintah.

Oleh karena itulah, untuk membangun kembali kepercayaan publik terhadap pelayanan perizinan khusus Surat Izin Usaha Perdagangan, pegawai DPMPTSP melakukan tugasnya dengan integritas yang tinggi dan sangat fokus untuk memberikan pelayanan perizinan pada masyarakat. Kondisi ini dapat tergambarkan dari penyampaian informasi yang jelas diberikan kepada masyarakat mulai dari prasyarat dalam mengurus SIUP hingga penerbitan izin usahanya. Hal ini sebagai upaya menghindarkan masyarakat dari rasa kebingungan dalam mendapatkan pelayanan perizinan perdagangan.

Keterbukaan terkait informasi dan seberapa jauh interaksi komunikasi yang terjalin antara birokrasi dengan masyarakat pengguna jasa juga menggambarkan bahwa suatu organisasi pelayanan publik dapat menyesuaiakn diri dengan lingkungannya sehingga hal ini berdampak ada kinrja pelayanan itu sendiri (Sinambela, 2008)

Dalam penelitian ini, kecermatan melayani berkaitan dengan kesungguhan dan fokus pegawai dalam melakukan penyampaian pelayanan terkait Surat Izin Usaha Perdagangan (SIUP) kepada masyarakat. Dalam pelayanannya, pegawai DPMPTSP terlebih dahulu akan mengarahkan masyarakat ke loket informasi. Mekanisme ini tidak hanya diterapkan dalam pengurusan izin usaha tetapi pada semua jenis pelayanan perizinan. Hal ini bertujuan agar masyarakat mendapatkan informasi yang jelas terkait dengan persyaratan dokumen yang harus dibawa dalam pengurusan izin usaha perdagangan di DPMPTSP.

Dalam hal kecermatan, peran yang penting juga dibebankan pada Tim Teknis yang bertugas untuk memberikan rekomendasi terkait penerbitan izin usaha perdagangan masyarakat. Keberadaan tim ini merupakan salah satu bentuk koordinasi yang dilakukan antara DPMPTSP berkoordinasi dengan Dinas Perdagangan dan Industri Kabupaten Sinjai.

Selain itu, untuk menghindari terjadinya diskomunikasi antara pegawai dan masyarakat yang bermohon SIUP maka saat melakukan survey lapangan, tim teknis terlebih dahulu akan menyampaikan agenda kedatangannya kepada pemohon. Hal ini bertujuan untuk lebih memudahkan penyampaian informasi bilamana terjadi ketidakcocokkan antara berkas permohonan dengan kondisi usahanya. Sehingga masyarakat pemohon SIUP pun menjadi lebih cepat dan tanggap untuk menyelesaikan kekurangan atau masalah yang terjadi.

Berdasarkan hasil observasi, keceramatan peagawai DPMPTSP Kabupaten Sinjai dapat dikatakan sangat baik sebab aparatur sangat fokus dalam melayani dan masyarakat pun sangat jelas menerima informasi terkait pelayanan SIUP.

5. Ketepatan waktu melayani

$\mathrm{Hal}$ ini berkaitan dengan pelaksanaan pelayanan masyarakat akan diselesaikan dalam kurun waktu yang telah ditentukan. Dalam hal pengurusan SIUP, pelayanan yang diberikan DPMPTSP selalu mengacu pada Standar Operasional Prosedur (SOP) yang telah ditetapkan sebelumnya.

Melalui keterbukaan terhadap informasi pelayanan, masyarakat juga dapat dengan tepat mengetahui seberapa lama waktu pelayanan dalam pengurusan SIUP. Di DPMPTSP sendiri, waktu pelayanannnya berpedoman pada SOP. SOP merupkan suatu acuan baku bagi birokrasi dalam memberikan pelayanan baik dari segi biaya maupun waktu pelayanan.

Selama ini, DPMPTSP selalu menyelesaikan penerbitan izin usaha sesuai dengan SOP bahwa waktu yang dibutuhkan pendapat lebih cepat dari 
waktu yang telah ditetapkan sebelumnya. Sehingga ini berdampak pada tercapainya efisiensi yang maskimal dalam pelayana SIUP di DPMPTSP.Sebagaimana yang dikatakan oleh Dwiyanto (2012: 76), pelayanan akan efisien apabila birokrasi pelayanan dapat menyediakan input seperti waktu dan biaya yang meringankan pengguna jasa. Ketepatan waktu pelayanan ini merupakan indikator penting untuk melihat seberapa jauh kemudahan akses publik terhadap pelayanan yang ditawarkan. Selain hal ini juga dapat mengambarkan terkait seberapa berkualitasnya produk/pelayanan yang ditawarkan.

6. Kemampuan menanggapai keluhan

Kemampuan menanggapi keluhan berkenaan dengan semua keluhan pelanggan direspon oleh petugas. Dalam penelitian ini terkait dengan kemampuan pegawai DPMPTSP dalam menangani keluhan ataupun pengaduan dari masyarakat terkait penerbitan Surat Izin Usaha Perdagangan (SIUP).

Untuk terus meningkatkan daya tanggapnya, organisasi publik pula dituntut harus dapat menyesuaikan diri dengan kebutuhan dan aspirasi masyarakat. Hal ini dapat dilihat dari adanya loket aduan yang dibentuk oleh DPMPTSP baik secara langsung maupun lewat email dan telepon. Ini sebagai bukti nyata bahwa instansi ini secara terbuka menerima aduan, kritik, serta saran dari pengguna jasa. Tidak hanya itu saja, peran DPMPTSP pun berlanjut hingga menindaklanjuti secara tepat dan cepat keluhan terkait pengurusan SIUP sehingga memberikan win-win solution bagi semua pihak.

Berdasarkan observasi, peneliti melihat adanya loket pengaduan yang dihadirkan oleh DPMPTSP Kabupaten Sinjai. Loket ini bertugas untuk menerima pengaduan dari masyarakat baik secara langsung, lewat surat maupun lewat telepon. Jenis pengaduan juga dikelompokan menjadi dua jenis, yakni pengaduan masalah dan aduan administrasi, seperti berubah nama kepemilikan dan lokasi usaha.
Tabel 2. Data Pengaduan SIUP

\begin{tabular}{|l|c|c|c|c|}
\hline \multirow{2}{*}{ No } & \multirow{2}{*}{ Tahun } & \multicolumn{2}{|c|}{ Jumlah Pengaduan } & \multirow{2}{*}{ Total } \\
\cline { 3 - 4 } & & $\begin{array}{c}\text { Admin- } \\
\text { istrasi }\end{array}$ & $\begin{array}{c}\text { Pen- } \\
\text { gaduan } \\
\text { Masalah }\end{array}$ & \\
\hline 1 & 2015 & 30 & 1 & 31 \\
\hline 2 & 2016 & 15 & - & 15 \\
\hline 3 & $\begin{array}{c}\text { s/d Ok- } \\
\text { tober 2017 }\end{array}$ & 28 & - & 28 \\
\hline
\end{tabular}

Sumber: Bagian Data dan Informasi DPMPTSP Kab. Sinjai

Selain itu, loket pengaduan ini tidak hanya menerima keluhan dari pemohon SIUP akan tetapi aduan/keluhan yang muncul dari masyarakat yang lainnya. Bilamana ada pengaduan yang diterima oleh DPMPTSP maka instansi ini dengan singgap akan segara menangani masalah tersebut.

Berdasarkan hasil observasi, dapat dikatakan bahwa kemampuan DPMPTSP dalam merespon keluhan/aduan masyarakat terkait SIUP sudah baik terbukti bahwa setiap aduan yang ada dapat diselesaikan dengan baik oleh instansi ini.

Adanya keterbukaan untuk menerima aduan maupun saran, dapat menjelaskan bahwa suatu organisasi pubik memilki responsivitas yang baik karena mampu beradaptasi dengan beragam aspirasi masyarakat. Sebagaimana dijelaskan oleh Dwiyanto (2011), kemampuan suatu organisasi beradaptasi diperlukan untuk membuat suatu organisasi publik mempertahankan eksistensinya serta mengembangkan dirinya mengikuti tuntutan pengguna jasa (masyarakat).

\section{PENUTUP}

\section{Kesimpulan}

Berdasarkan hasil penelitian, maka dapat kami simpulkan bahwa repsonsivitas pelayanan publik dalam pengurusan Surat Izin Usaha Perdagangan di Dinas Penanaman Modal dan Pelayanan Terpadu Satu Pintu (DPMPTSP) Kabupaten Sinjai sudah berjalan dengan baik. Hal ini dapat dilihat dari 6 indikator yang kami gunakan, 
yaitu: Pertama, dalam kemampuan merespon masyarakat, pegawai DPMPTSP dinilai sangat ramah dan sopan dalam memberikan pelayanan kepada masyarakat. Kedua, dalam aspek kecepatan melayani, pegawai DPMPTSP sangat singgap dan tulus dalam memberikan pelayanan terhadap pemohon SIUP.Ketiga, ketepatan melayani. Aparatur DPMPTSP telah melayani sesuai dengan keinginan masyarakat yang tentunya berdasarkan pada Standar Operasional Prosedur (SOP) instansi. Keempat, aspek kecermatan melayani, artinya staf DPMPTSP benar-benar fokus dalam melayani serta sangat jelas dalam memberikan infomasi pelayanan terhadap pengguan jasa. Kelima aspek ketepatan waktu. DPMPTSP dapat menyelesaikan penerbitan SIUP masyarakat dalam 5 hari kerja bahkan terkadang lebih cepat dari standar waktu yang telah ditetapkan sebelumnya. Keenam, dalam kemampuan menanggapi keluhan/aduan dari masyarakat, DPMPTSP telah menyediakan loket aduan yang tidak hanya berfungsi untuk menampuang aspirasi masyarakat namun juga bertugas untuk menindaklanjuti keluhan dan saran dari publik secara cepat dan tepat. Namun, tak dapat dipungkiri, ada faktor penghambat yang biasanya menjadi kendala dalam proses penerbitan surat izin usaha perdagangan, yakni komunikasi antara aparatur DPMPTSP dengan pemohon izin usaha serta lokasi usaha pemohon yang cenderung jauh untuk dijangkau sehingga menghambat proses penerbitan SIUP.

\section{Saran}

Berdasarkan hasil penelitian dan kesimpulan yang telah dipaparkan, maka saran yang diberikan oleh peneliti, yaitu:

DPMPTSP tetap harus menjagaa dan meningkatkan responsivitasnya dalam memberikan pelayanan kepada masyarakat karena tiap hari tuntutan dan kebutuhan masyarakat akan semakin meningkat. Hal ini juga untuk mempertahankan kinerja pelayanan DPMPTSP yang berkualitas

Untuk memudahkan dalam penerbitan izin usaha, DPMPTSP perlu memanfaatkan kemajuan Informasi
Teknologi (IT) dalam melakukan survei lapangan.

\section{DAFTAR PUSTAKA}

Creswell J.W. (2010). Research Design : Pendekatan Kualitatif, Kuantitatif dan Mixed. Yogyakarta: Pustaka Pelajar

Dwiyanto, Agus. 2006. MewujudkanGood Governance dalam Pelayanan Publik. Yogyakarta : Gadjah Mada University Press

-----------. 2008. Reformasi Birokrasi Publik di Indonesia. Yogyakarta : Gadjah Mada University Press

-----------. 2011. Mengembalikan Kepercayaan Publik Melalui Reformasi Birokrasi. Jakarta : Gramedia Pustaka Utama

Gita,2016.Model Kebijakan Pemberdayaan Masyarakat Terintegrasi: studi kasus implementasi kebijakan pemberdayaan masyarakat nelayan di wilayah pesisir Provinsi Sulawesi Selatan. Journal of Government and Politics :Universitas Muhammadiyah Malang.

Hardiansyah. 2011. Kualitas Pelayanan Publik : Konsep, Dimensi, Indikator dan Implementasinya. Yogyakarta : Gava Media

Mansyur. 2015. Revitalisasi Birokrasi dalam Pelayanan Perizinan di Kabupaten Sinjai (Disertasi). Program Pascasarjana Universitas Negeri Makassar

Pasolong, Harbani. 2007. Teori Administrasi Publik. Bandung : Alfabeta

Sukmawati. 2016. Akuntabilitas Proses Pelayanan Surat Izin Usaha Perdagangan (SIUP) di Kota Makassar (Skripsi). Universitas Hasanuddin

Sinambela, Lijan P dkk. 2008. Reformasi Pelayanan Publik : Teori, Kebijakan dan Implementasi. Jakarta : Bumi Aksara 
Tjiptono, Fandy. 2008. Service Management: Mawujudkan Layanan Prima. Yogyakarta: Andi Offset.

\section{Peraturan Pemerintah :}

Peraturan Bupati Sinjai No 9 Tahun 2016 Tentang Pelimpahan Kewenangan Pengelolaan dan Penandatanganan Perizinan dan Non Perizinan pada Badan Penanaman Modal dan Pelayanan Perizinan Kabupaten Sinjai

Peraturan Daerah Kabupaten Sinjai No 19 Tahun 2000 Tentang Pembentukan Organisasi dan Tata Kerja lembaga Teknis dan Lembaga Non Teknis

Keputusan Bupati Sinjai No 58 Tahun 2015 tentang Badan Penanaman Modal dan Pelayanan Perizinan Kabupaten Sinjai

\section{Sumber Internet :}

https://sinjai.info/ptsp-sinjai-sosialisasijenis-pelayanan/. Diakses tanggal 5 Juli 2017. 